\title{
18. The Causal Agent of Rice Grassy Stunt Disease
}

\author{
By Eishiro Shikata, Toshihiro Senboku, and Taeko Ishimizu \\ Department of Botany, Faculty of Agriculture, \\ Hokkaido University, Sapporo
}

(Communicated by Naohide Hiratsuka, M. J. A., Feb. 12, 1980)

Rice grassy stunt disease was first noticed in 1962 at the International Rice Research Institute (IRRI) in the Philippines. The disease agent was demonstrated to be transmitted by brown planthopper, Nilaparvata lugens Stål in the persistent manner.5),11) Subsequently the disease has been reported from Ceylon, ${ }^{1)}$ Thailand, ${ }^{12)}$ India ${ }^{10)}$ and quite recently it was found in the Kyushu district of Japan (A. Shinkai, personal communication).

Diseased rice plants are severely stunted and develop excess tillering that produces a bushy appearance. The affected leaves become short and narrow, yellowish green in color with scattered numerous rusty spots. The symptoms resemble, to some extent, those of rice yellow dwarf disease, but the infected leaves of grassy stunt disease are narrower and more green than those caused by yellow dwarf disease. In addition, no rusty spots appear on the infected foliage of yellow dwarf disease.

At present, there is no confirmed information available on the causal agent of the disease, although it was suspected to be induced by a mycoplasma like organism (MLO).$^{7), 8)}$ In this paper it was intended to report the results of the experiments on purification and electron microscopy of rice grassy stunt agent, and to demonstrate that the disease is caused by a virus.

Materials. The vector insects, $N$. lugens, collected in the fields in Japan and confined in insect cages in the greenhouse were used for the transmission experiments. The diseased rice plants were supplied by The International Rice Research Institute, Philippines. The disease was successively transmitted to the healthy plants of the japonica rice varieties (Norin no. 8 and Mihonishiki) by the insects and they were maintained in the greenhouse of Hokkaido University, Sapporo, Japan.

Effect of antibiotics and sulpha drug. Because the disease symptoms resemble those of rice yellow dwarf disease, which is caused by a MLO, it was attempted to examine the effect of such chemicals as harmful to MLO, Clamydia and Rickettia upon the causal agent of grassy stunt disease. The chemicals used are sulpha drug (sulfiso- 
midin), tetracycline (oxytetracycline hydrochloride, tetracycline hydrochloride), chloramphenicol (chloramphenicol sodium succinate) and penicillin (crystalline pottassium penicillin G). The chemicals were applied to the diseased rice plants through roots at $10,50,100$, 200 and $400 \mathrm{ppm}$ for $24 \mathrm{hrs}$, and the treated plants were grown in the water culture solution for 2 weeks. The chemicals were applied 2 times at interval of 2 weeks. None of the plants treated by those chemicals recovered from the disease, whereas the plants infected with rice yellow dwarf disease were apparently cured by tetracycline, but its causal agent was resistant to sulpha drug, chloramphenicol and penicillin. The result suggests that rice grassy stunt disease is not caused by MLO, Clamydia and Rickettia.

Insect transmission and host range. Second instar nymphs which were fed on the diseased rice plants for 7 days and confined on healthy rice plants for 2 weeks were transferred individually to healthy young rice seedlings. The result indicated that 23 out of $141(16.3 \%)$ inoculated seedlings showed typical symptoms of grassy stunt disease 2 to 3 weeks after inoculation. It was shown that the insects collected in Japan were capable of transmitting the disease with similar transmissibility to those captured in the Philippines, and the japonica rice varieties were susceptible to the disease.

Young seedlings of barley, wheat, oat, maize, Panicum crus-galli var. frumentaceum Hook, P. milliaceum L. and Coix lachryma-jobi var. frumentaceum Makino were inoculated by 8 viruliferous insects per plant for 7 days. None of the plants showed the symptoms even 2 months after inoculation. The back-inoculation from those inoculated plants to rice failed to show grassy stunt disease symptoms.

Artificial injection. Extracts from the diseased rice leaves in the equal volume of $0.025 \mathrm{M}$ phosphate buffer at $\mathrm{pH} 6.0$ or those from viruliferous insects in 20 volumes $(\mathrm{V} / \mathrm{W})$ of $0.1 \mathrm{M}$ ammonium acetate buffer at $\mathrm{pH} 7.0$ were centrifuged at $3,000 \mathrm{rpm}$ for $15 \mathrm{mins}$. The supernatants were then injected into abdomens of healthy 2 nd instar nymphs of $N$. lugens by fine glass capillaries. The result is shown in Table I. About 8 to $19 \%$ and 10 to $25 \%$ of the insects injected with extracts from the diseased rice plants and from the viruliferous insects, respectively, became transmitters 2 weeks after inoculation. The result indicates that the disease agent is supposedly propagative in the insect vectors.

Purification. Fresh diseased rice leaves were macerated in two volumes $(\mathrm{V} / \mathrm{W})$ of $0.2 \mathrm{M}$ Tris buffer containing $0.01 \mathrm{M}$ thioglycolic acid, $\mathrm{pH}$ 6.5, then filtered twice through a layer of celite in a Buchner's funnel. The filtrates were then centrifuged by high speed centrifugation at $45,000 \mathrm{rpm}(143,000 \mathrm{~g})$ for 120 mins. The resultant pellets 
Table I. Result of artificial injection of rice grassy stunt virus

\begin{tabular}{cccccc}
\hline Virus source & $\begin{array}{c}\text { No. of } \\
\text { insects } \\
\text { injected }\end{array}$ & $\begin{array}{c}\text { No. of } \\
\text { insects } \\
\text { survived } \\
\text { after } \\
\text { 2 weeks }\end{array}$ & $\begin{array}{c}\text { No. of } \\
\text { plants } \\
\text { inoculated }\end{array}$ & $\begin{array}{c}\text { No. of } \\
\text { insects } \\
\text { per } \\
\text { plant }\end{array}$ & $\begin{array}{c}\text { No. of } \\
\text { plants } \\
\text { infected }\end{array}$ \\
\hline Diseased rice leaves & 60 & 19 & 13 & 1 & $1(7.7 \%)$ \\
\hline Viruliferous insects & 180 & 78 & 21 & 3 & $4(19.0 \%)$ \\
\hline
\end{tabular}

were dissolved in the buffer, $\mathrm{pH} 7.5$ and clarified by a low speed centrifugation at $10,000 \mathrm{rpm}$ for $15 \mathrm{mins}$. The materials were placed on the sucrose density gradient column (10-40\% sucrose) and centrifuged at 25,000 rpm for $180 \mathrm{mins}$. The column was then divided into 4 fractions, and each was further concentrated into $0.2 \mathrm{ml}$ of the buffer solution after one cycle of differential centrifugation. Each of the concentrated fractions was then injected into healthy nymphs for infectivity tests. As shown in Table II, fraction no. 3, about 4.2-

Table II. Infectivity of purified preparations of rice grassy stunt virus

\begin{tabular}{cccccc}
\hline $\begin{array}{c}\text { No. of } \\
\text { fractions* }\end{array}$ & $\begin{array}{c}\text { No. of } \\
\text { insects } \\
\text { injected }\end{array}$ & $\begin{array}{c}\text { No. of } \\
\text { insects } \\
\text { survived } \\
\text { after } \\
\text { 2 weeks }\end{array}$ & $\begin{array}{c}\text { No. of } \\
\text { plants } \\
\text { inoculated }\end{array}$ & $\begin{array}{c}\text { No. of } \\
\text { insects per } \\
\text { plant for } \\
\text { inoculation }\end{array}$ & $\begin{array}{c}\text { No. of } \\
\text { plants } \\
\text { infected }\end{array}$ \\
\hline 1 & 80 & 33 & 11 & 3 & 0 \\
2 & 80 & 39 & 13 & 3 & $4(30.8 \%)$ \\
3 & 80 & 36 & 12 & 3 & $10(83.3 \%)$ \\
4 & 80 & 42 & 14 & 3 & $4(28.6 \%)$ \\
control** & 80 & 39 & 13 & 3 & $5(38.5 \%)$ \\
\hline
\end{tabular}

* Each fraction (nos. 1-4) was concentrated in a $0.2 \mathrm{ml}$ buffer solution after high speed centrifugation, and then injected into abdomens of healthy insects. ** A concentrated partially purified virus preparation before sucrose density gradient centrifugation.

$6.3 \mathrm{~cm}$ from the meniscus, was highly infectious. Whereas the infectivity recovered from fraction nos. 2 and 4 was relatively low. Electron micrographs taken from fraction no. 3 revealed numerous small isometric particles, about $20 \mathrm{~nm}$ in diameter. The particles of the same size and shape were scarcely found in the preparations from fraction nos. 2 and 4, but not from fraction no. 1 which was not infections. No such small isometric particles were obtained from healthy rice plants. The particles in fraction no. 3 frequently appeared as dimers (Fig. 1).

Ultrathin sections. Small pieces $(1 \times 3 \mathrm{~mm})$ of the diseased rice leaves, abdomens and salivary glands dissected from the individually 


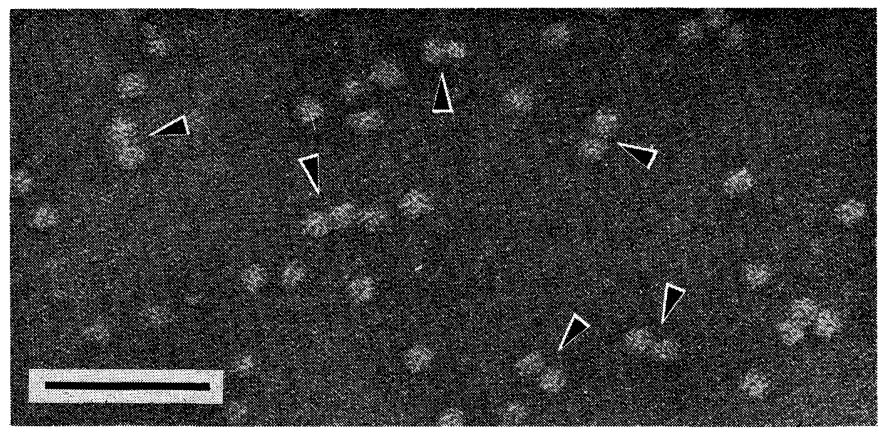

Fig. 1. An electron micrograph of purified virus particles in fraction no. 3 isolated from the diseased rice leaves. Arrows indicate dimers. 2\% UA stain. Bar represents $100 \mathrm{~nm}$.

tested viruliferous insects were fixed and embedded in epoxy resin by the previously described procedures (Chen and Shikata, 1971; Shikata and Maramorosch, 1967). Ultrathin sections were cut using a Porter-Blum MT-1 ultramicrotome equipped with glass or diamond knives, and double stained in $2 \%$ uranyl acetate and lead citrate for $60 \mathrm{mins}$ and $15 \mathrm{mins}$, respectively.

Electron micrographs of the cells from the diseased rice leaves

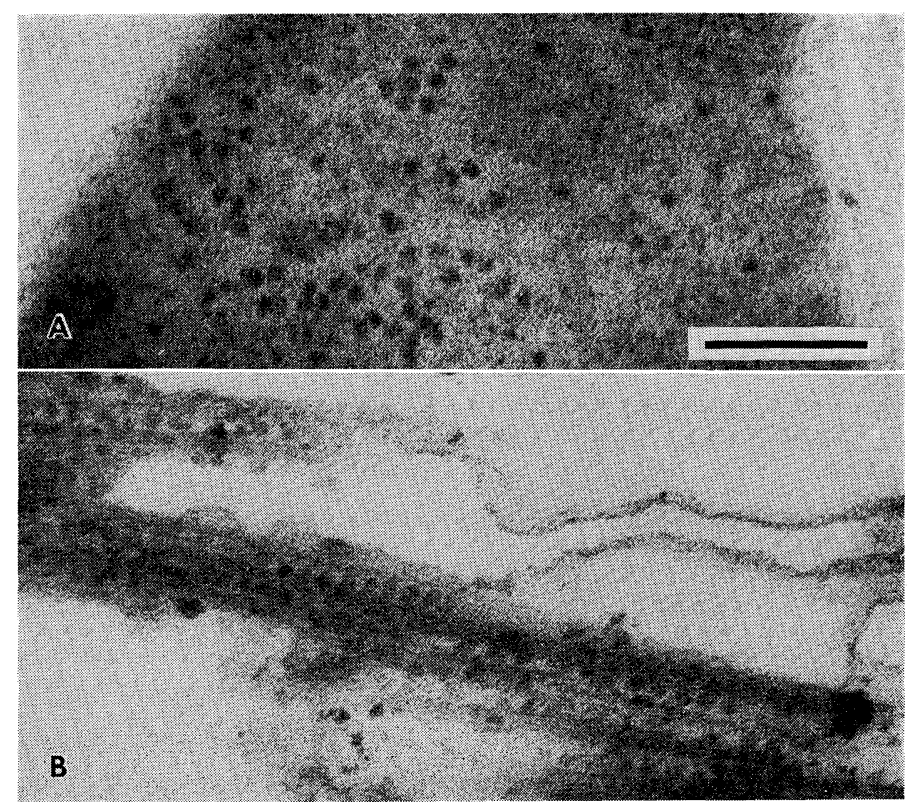

Fig. 2. Electron micrographs of ultrathin sections of phloem cells from the diseased rice leaves. Bar represents $200 \mathrm{~nm}$. A: Scattered virus particles appeared in a degenerated phloem cell. B: Accumulation of a row of virus particles arranged within the fine tubules encountered in a phloem cell. 
revealed small isometric particles, about $20 \mathrm{~nm}$ in diameter, scattering or accumulating within cytoplasm of the phloem cells, as shown in Fig. 2. The size and shape of those particles resemble those of the purified particles of the grassy stunt disease agent. No such particles were found in cells of healthy rice leaves. A row of the virus particles arranged within fine tubules are rarely found in some of the phloem cells. The structure of those tubules are similar to "tubular formations including $25 \mathrm{~nm}$ particles". ${ }^{9}$ ) The particles with the same size and shape were found in a crystalline arrangement in cells of fat body and trachea of the viruliferous insects (Fig. 3).

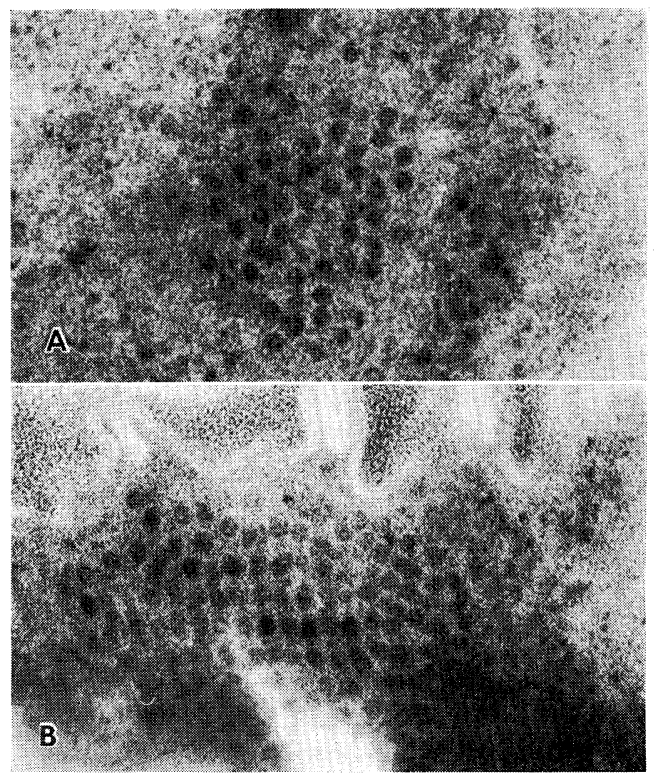

Fig. 3. Electron micrographs of ultrathin sections of the individually tested viruliferous insects. Same magnification as Fig. 2. A: A cluster of virus particles found in a fat body cell. B: A crystalline array of virus particles found in a trachea cell.

In the course of the preliminary experiments, we found that the disease agent was extremely labile by the treatment with several organic solvents that have been commonly used for the viral purification. We experienced great difficulties for the purification of the grassy stunt agent. Although our final preparation was not thoroughly purified, it is most likely that the small isometric particles isolated from the diseased plants are the causal virus of grassy stunt disease, since the infectivity constantly associated with the preparations containing the particles, and in addition, the particles of the same size and shape were abundantly found within cells of the infected rice leaves and the viruliferous insects. 
Rivera et al. (1966) demonstrated that the grassy stunt disease agent was persistently transmitted in its insect vectors. The results obtained in our insect transmission experiments by artificial injection, also indicated that the causal agent would be propagative in the insect vector. Most of the propagative leafhopper borne plant viruses have virions of large isometric particles, $70-80 \mathrm{~nm}$ in diameter, large bacilliform or threads. No small isometric particles were reported to be propagative in the insect vector so far. Rice tungro virus is a small isometric particles about $30 \mathrm{~nm}$ in diameter and known to be transmitted in a non-persistent manner by leafhopper vectors. ${ }^{6)}$ Another small isometric particles, $25 \mathrm{~nm}$ in diameter, is rice yellow mottle virus which is transmitted by the beetle vectors. ${ }^{2)}$ Beet curly top virus also has a small particle, $20 \mathrm{~nm}$ in diameter that is known to be transmitted in a circulative manner by the leafhopper vectors..$^{3), 4)}$ It is worthy of note that rice grassy stunt virus having a small isometric structure is propagative in its insect vectors.

Acknowledgements. The authors express sincere appreciation to Dr. T. Fukushi, Emer. Professor, Hokkaido University for his kind suggestions for preparing the manuscript. We also thank Dr. K. C. Ling and Mr. E. R. Tiongco, IRRI, who kindly prepared and supplied the diseased rice materials.

\section{References}

1) Abeygunawardena, D. V. W. (1969): The Virus Diseases of the Rice Plants. IRRI, Johns Hopkins Press, Baltimore, pp. 53-57.

2) Bakker, W. (1974): Agr. Res. Rept., Centre for Agr. Publ. Document., Wageningen, 829, 1-152.

3) Duffs, J. E., and A. H. Gold (1973) : Phytopathology, 63, 1107-1110.

4) Esau, K. (1977) : J. Ultrastr. Res., 61, 78-88.

5) IRRI (1964): Annual Report for 1964. The International Rice Research Institute, Los Baños, Philippines.

6) Ling, K. C. (1966) : Phytopathology, 56, 1252-1256.

7) Maramorosch, K., R. R. Granados, and H. Hirumi (1970): Advances in Virus Res., 16, 135-193.

8) Ou, S. H. (1972) : Rice Diseases. Commonwealth Mycol. Inst., Kew, Surrey, $368 \mathrm{pp}$.

9) Pellegrini, S., and M. Bassi (1978): Phytopath. Z., 92, 247-250.

10) Raychaudhuri, S. P., M. D. Mishra, and A. Ghosh (1967) : Plant Dis. Reptr., 51, 300-301.

11) Rivera, C. T., S. H. Ou, and T. Iida (1966) : Plant Dis. Reptr., 50, 453-456.

12) Wathanakul, L., and P. Weerapat (1969): The Virus Diseases of the Rice Plants. IRRI, Johns Hopkins Press, Baltimore, pp. 79-85. 